Krzysztof Skotnicki

Uniwersytet Łódzki

\title{
W sprawie dopuszczalności zakazu reelekcji wójta (burmistrza, prezydenta miasta) po piastowaniu urzędu przez dwie kadencje ${ }^{*}$
}

DOI: $10.19195 / 1643-0328.24 .1$

Słowa kluczowe: samorząd terytorialny, wybory, gmina, wójt, kadencyjność

\section{Wprowadzenie}

Jednym $\mathrm{z}$ tematów, który dominuje $\mathrm{w}$ ostatnim czasie $\mathrm{w}$ debacie publicznej, jest zapowiedź przedstawicieli Prawa i Sprawiedliwości, iż jako rządzące obecnie w Polsce ugrupowanie polityczne będzie dążyć do ustanowienia ograniczenia podczas wyborów samorządowych możliwości kandydowania na urząd wójta (burmistrza, prezydenta miasta) przez osoby, które piastują ten urząd już przez dwie bądź więcej kadencji. Posiadana przez tę partię w Sejmie i w Senacie większość głosów sprawia, że z uchwaleniem stosownej regulacji ustawowej nie będzie żadnego problemu. Temperaturę dyskusji podnosi przy tym fakt, że proponowane rozwiązanie miałoby obowiązywać już podczas najbliższych wyborów samorządowych, których ustawowy termin przypada na jesień 2018 r. W sporach, które mają miejsce, uczestniczą zarówno politycy, samorządowcy (w tym w szczególności oczywiście ci, którzy pełnią już swoje urzędy organu wykonawczego w gminie co najmniej przez dwie kadencje), przedstawiciele nauki, jak i obywatele, którzy są szczególnie żywo zainteresowani tym, kto będzie rządził w gminie, w której

* Już po złożeniu tekstu do druku i zakończeniu prac redakcyjnych w dniu 11 stycznia 2018 r. została uchwalona ustawa o zmianie niektórych ustaw w celu zwiększenia udziału obywateli w procesie wybierania, funkcjonowania i kontrolowania niektórych organów publicznych (Dz.U. 2018 poz. 130). W art. 5 ustanowiła ona nowelizację Kodeksu wyborczego, wprowadzając w dodanym ust. 4 art. 11, że prawa wybieralności $\mathrm{w}$ wyborach wójta (burmistrza, prezydenta miasta) nie ma w danej gminie osoba, która została uprzednio dwukrotnie wybrana na wójta (burmistrza, prezydenta miasta) w tej gminie. Jednocześnie w art. 17 ustanowiono, że dodany przepis nie dotyczy wybrania na wójta, burmistrza lub prezydenta miasta przed dniem wejścia w życie ustawy nowelizującej, co oznacza, że ustanowiona zasada zacznie obowiązywać dopiero od wyborów samorządowych w $2018 \mathrm{r}$. 
na stałe zamieszkują. W dyskusji przywoływane są różne racje przemawiające za i przeciwko takiemu rozwiązaniu. Wiele argumentów jest przy tym natury czysto prawnej. Celem tego opracowania jest odniesienie się do tych zagadnień, w tym przede wszystkim do wypowiadanych wywodów prawniczych, nie zawsze bowiem są one prawdziwe.

\section{Propozycje ustanowienia zakazu reelekcji wójta (burmistrza, prezydenta miasta)}

Przede wszystkim należy przypomnieć, że zgłoszona propozycja ograniczenia możliwości kandydowania na urząd wójta (burmistrza, prezydenta miasta) przez osobę, która pełniła już tę funkcję przez co najmniej dwie kadencje, absolutnie nie jest nowa i co pewien czas jest ponownie zgłaszana przede wszystkim przez polityków. Środowisko naukowe jest natomiast znacznie bardziej powściągliwe w wysuwaniu takiego postulatu. Należy tė̇ podkreślić, że prezentowane w tym zakresie opinie formułowane były przed laty, dlatego trudno zarzucić im, iż przedstawiana ocena ma obecnie jakikolwiek podtekst polityczny. W niniejszym opracowaniu przypominam te poglądy oraz bazuję na dwóch opiniach, jakie przygotowałem dla Biura Analiz Sejmowych ${ }^{1}$.

W pracach Sejmu po raz pierwszy pojawiła się ona już w trakcie IV kadencji. Grupa posłów z Klubu Parlamentarnego Sojuszu Lewicy Demokratycznej zainicjowała wówczas, w dniu 21 listopada 2001 r., podjęcie ustawy o bezpośrednim wyborze wójta gmi$n y^{2}$. Regulacja miała odnosić się wyłącznie do gmin do 20000 mieszkańców i przewidywano w niej między innymi, że ponowny wybór tej samej osoby na wójta w tej samej gminie może mieć miejsce tylko raz (art. 2 ust. 2). Rozwiązania tego nie uzasadniono jednak, w toku dalszych prac nad projektem ustawy zaś z ograniczenia tego zrezygnowano, dlatego nie zawierała go ustawa $z$ dnia 20 czerwca 2002 r. o bezpośrednim wyborze wójta, burmistrza i prezydenta miasta ${ }^{3}$. Od tamtego czasu zaczęto jednak wracać do tego rozwiązania tak w pracach parlamentarzystów, jak i w opracowaniach naukowych ${ }^{4}$.

Następny raz powrócono do idei ograniczenia możliwości ubiegania się o funkcje w organach wykonawczych samorządu terytorialnego w Sejmie VI kadencji. Z propozycją taką wystąpiła grupa posłów na Sejm RP Klubu Parlamentarnego „Prawo i Sprawie-

${ }^{1}$ Są to opinie prawne: $\mathrm{z}$ dnia 28 października 2010 r. Opinia prawna na temat zgodności z Konstytucją art. 2 i art. 4-6 poselskiego projektu ustawy - o zmianie ustawy o samorządzie gminnym oraz o zmianie innych ustaw zgłoszonego w dniu 21 września 2010 r. przez Grupę posłów na Sejm RP Klubu Parlamentarnego „Prawo i Sprawiedliwość” oraz z dnia 15 listopada 2013 r. Opinia prawna na temat poselskiego projektu ustawy o zmianie ustawy z 5 stycznia 2011 r. - Kodeks wyborczy poprzez ustanowienie ograniczenia wykonywania mandatu posła, senatora oraz sprawowania urzędu wójta (burmistrza, prezydenta miasta) jedynie przez dwie kadencje (zlecenie 2692/13).

2 Zob. druk sejmowy nr 154.

${ }^{3}$ Ustawa z dnia 20 czerwca 2002 r. o bezpośrednim wyborze wójta, burmistrza i prezydenta miasta, Dz.U. z 2002 r. Nr 113, poz. 984. Po nowelizacjach ogłoszony był tekst jednolity Dz.U. z 2010 r. Nr 176, poz. 1191.

${ }^{4}$ Szerzej zob. M. Tarasek, Wprowadzenie ograniczenia kadencyjności wójta, burmistrza, prezydenta miasta w pracach polskiego parlamentu, „Polityka Społeczna” 2016, nr 2, s. 83-95. 
dliwość". W zgłoszonym w dniu 21 września 2010 r. projekcie ustawy o zmianie ustawy o samorządzie gminnym oraz o zmianie innych ustaw proponowali oni ograniczenie możliwości kandydowania na funkcję wójta (burmistrza, prezydenta miasta), a początkowo również starosty i marszałka województwa przez osobę, która pełniła już tę funkcję przez co najmniej dwie kadencje ${ }^{5}$. Pomimo wielu pozytywnych opinii na temat tego rozwiązania, jak i uznania przez Komisję ustawodawczą, że jest on dopuszczalny, projekt został odrzucony w I czytaniu w dniu 1 kwietnia 2011 r.

Propozycja została powtórzona przez posłów Prawa i Sprawiedliwości już na początku VII kadencji Sejmu, gdy 29 listopada 2011 r. zgłosili oni poselski projekt ustawy o zmianie ustawy o samorządzie gminnym oraz o zmianie innych ustaw ${ }^{6}$. Projekt ów również został jednak odrzucony podczas I czytania w dniu 15 czerwca $2012 \mathrm{r}$.

Kolejną propozycję ograniczenia możliwości kandydowania podczas wyborów wójta (burmistrza, prezydenta miasta) zgłosili posłowie z Klubu Palikota. Po raz pierwszy uczynili to w dniu 9 listopada $2012 \mathrm{r}$. W przedłożonym wówczas projekcie nowelizacji Kodeksu wyborczego proponowali, aby nie można było kandydować na stanowisko wójta (burmistrza, prezydenta miasta) po dwukrotnym sprawowaniu tego urzędu ${ }^{7}$. Odrzucenie tego projektu nastąpiło już w pierwszym czytaniu w dniu 8 lutego 2013 r. Niezrażeni niepowodzeniem posłowie tego Klubu ponowili jednak swój wniosek w projekcie nowelizacji Kodeksu wyborczego zgłoszonym jesienią 2013 r. Tym razem proponowali jednak, aby ograniczenie możliwości kandydowania z uwagi na odbyte już dwie kadencje dotyczyło nie tylko wójtów (burmistrzów, prezydentów miast), ale również posłów i senatorów. Do uchwalenia tych zmian i tym razem jednak nie doszło.

Obecny powrót do możliwości sprawowania kadencji wójta (burmistrza, prezydenta miasta) został po raz pierwszy sformułowany przez Andrzeja Derę, ministra w Kancelarii Prezydenta RP, w rozmowie z Rafałem Kergerem, redaktorem naczelnym PortalSamorządowy.pl. Następnie był on powtarzany przez polityków Prawa i Sprawiedliwości, $\mathrm{w}$ tym przede wszystkim znalazł się w kilku wypowiedziach medialnych lidera tej partii, Jarosława Kaczyńskiego.

Wnioskiem, jaki niewątpliwie nasuwa się po przypomnieniu historii propozycji projektów ustaw odnoszących się do ograniczenia liczby kadencji sprawowanych przez wójtów (burmistrzów, prezydentów miast), jest to, że problem ten zgłaszany jest nie tylko od dawna, lecz - przede wszystkim - przez różne i diametralnie sobie przeciwne pod względem programów ugrupowania polityczne. Już sam ten fakt, nawet bez przywoływania argumentacji za takim rozwiązaniem, musi skłaniać do refleksji na temat zasadności projektu $\mathrm{i}$ to nawet pomimo tego, że obecnie stanowisko SLD nie jest już tak jednoznaczne odnośnie do ustanowienia ograniczenia w możliwości piastowania urzędu wójta (burmistrza, prezydenta miasta) przez więcej niż dwie kadencje, a nawet wydaje się tej idei przeciwne.

\footnotetext{
5 Druk sejmowy nr 3834.

${ }^{6}$ Druk sejmowy nr 428.

${ }^{7}$ Druk sejmowy nr 1015.
} 


\section{Argumenty przemawiające za ustanowieniem zakazu reelekcji wójta (burmistrza, prezydenta miasta)}

Uzasadnienie przywoływane we wszystkich wnioskach za ustanowieniem omawianego ograniczenia w możliwości kandydowania jest zawsze takie samo. Podnosi się w nim, że tak samo jak w przypadku Prezydenta, który zgodnie z art. 5 ust. 2 Konstytucji może być ponownie wybrany na ten urząd tylko raz, prawo ma na celu uniemożliwienie koncentracji władzy w rękach jednej osoby (a czasami nawet konkretnego środowiska politycznego) przez zbyt długi czas. Podkreśla się, że w wielu gminach te same osoby kierują nimi od początku przywrócenia samorządu w gminach, a niektóre spośród nich piastowały w poprzednim ustroju nawet stanowisko naczelnika gminy. W wielu gminach urzędujący wójt, burmistrz czy prezydent miasta ubiegający się o ponowny wybór nie ma nawet kontrkandydata, co sprawia, że wyborcy nie uczestniczą w głosowaniu, gdyż nie mają wyboru $^{8}$. Po wyborach z 2014 r. na 108 prezydentów miast aż 48, czyli 44,86\% spośród nich, sprawuje swój urząd od co najmniej trzech kadencji ${ }^{9}$. Sytuacja taka z jednej strony sprzyja powstawaniu patologicznych sytuacji, korupcji i sieci lokalnych powiązań interesów, czyli tzw. układów uniemożliwiających uzyskanie pracy, zlecenia czy decyzji administracyjnych przez osoby spoza tego kręgu, co oczywiście budzi sprzeciw społeczny. $\mathrm{Z}$ drugiej jednak strony powoduje również pewne popadanie w rutynę, niedostrzeganie wielu spraw, wręcz wypalenie intelektualne, które uniemożliwia podejmowanie nowych inicjatyw, do których potrzebne są nowe osoby, które mając inne spojrzenie, rozpoczną ich realizację. Pojawia się również argument, że doświadczenie zdobyte przez osoby będące przez dwie kadencje wójtami, burmistrzami czy prezydentami miast można później z powodzeniem wykorzystać w funkcjonowaniu organów samorządowych powiatu bądź województwa, a nawet w pracy organów władzy państwowej, w szczególności Sejmu i Senatu. Podnoszone jest wreszcie, że podobne ograniczenia stosowane są w wielu państwach i jest to na tyle częste, że ukute zostało określenie term limit. Wśród głosów opowiadających się za tym rozwiązaniem pojawiają się co najwyżej propozycje, aby wydłużyć kadencję organu wykonawczego gminy do pięciu lat.

\section{Argumenty przemawiające przeciwko ustanowieniu zakazu reelekcji wójta (burmistrza, prezydenta miasta)}

Przeciwnicy wprowadzenia ograniczenia możliwości ponownego kandydowania przez wójtów, burmistrzów czy prezydentów miast w przypadku sprawowania przez nich co najmniej dwóch kadencji na tym stanowisku stawiają natomiast zarzut, że rozwiązanie takie odbiera lokalnym społeczeństwom prawo decydowania we własnych sprawach, a więc uderza w samorządność. Wskazują, że właśnie po to ustanowiono w 2002 r. bez-

\footnotetext{
${ }^{8}$ W 2006 r. było 96 takich przypadków, w 2010 r. aż 301, a w 2014 r. nieco mniej, gdyż 246. Podaję za: M. Tarasek, op. cit., s. 88.

${ }^{9}$ Ibidem.
} 
pośrednie wybory organu wykonawczego gminy, aby to mieszkańcy sami decydowali o tym, kto ma piastować tę funkcję, kogo uznają za najwłaściwszego (najlepszego) do sprawowania tego urzędu. Jest to istotne rozwiązanie w budowaniu społeczeństwa obywatelskiego. Sprawowanie urzędu przez więcej niż dwie kadencje nie jest złe, gdyż pozwala na realizację pewnej wizji rozwoju gminy, która znacznie wykracza poza osiem lat, a osoba piastująca urząd ma wielkie doświadczenie. Trudno też zestawiać zadania, jakie ma Prezydent Rzeczypospolitej Polskiej, z tymi, które należą do organu wykonawczego gminy, dlatego i zasadność ograniczenia liczby sprawowanych kadencji nie może być argumentowana w ten sposób. Podkreśla się również, że niezadowoleni mieszkańcy mają możliwość wybrania innego kandydata, istnieje też prawo odwołania organu wykonawczego (jak i stanowiącego) gminy w drodze referendum, co w praktyce ma przecież miejsce nie tylko w małych gminach, ale nawet w tak dużych, jak Łódź czy Częstochowa. Obecnie często podnoszony jest również zarzut, że propozycja wprowadzenia wskazanego ograniczenia ma na celu wyłącznie pozbycie się politycznych konkurentów, gdyż bez tego jest bardzo trudne albo nawet wręcz niemożliwe wygranie z nimi rywalizacji podczas wyborów ${ }^{10}$.

Wśród argumentów używanych przeciwko wprowadzeniu ograniczenia możliwości ponownego kandydowania wójtów, burmistrzów czy prezydentów miast w przypadku sprawowania przez nich co najmniej dwóch kadencji na tym stanowisku wysuwany jest również taki, że jest to rozwiązanie naruszające prawo, sprzeczne z Konstytucją. Niestety tylko czasami jest to uzasadniane, gdyż na ogół poprzestaje się wyłącznie na samym stwierdzeniu istnienia takiej niezgodności. Jeżeli już jednak jest to konkretyzowane, to najczęściej mowa jest o ograniczeniu biernego prawa wyborczego, o naruszeniu zakazu retroaktywności, ewentualnie zbyt krótkim vacatio legis przed zapowiadanym wejściem tego rozwiązania w życie. Tym kwestiom będą poświęcone dalsze rozważania.

\section{Zakaz reelekcji wójta (burmistrza, prezydenta miasta) w świetle regulacji konstytucyjnej}

Przede wszystkim należy stwierdzić, że konstytucyjna regulacja wyborów do organów samorządu terytorialnego (podobnie zresztą jak wyborów do Senatu) jest zasadniczo bardzo lakoniczna. W moim przekonaniu jest to w pełni zasadnie krytykowane, ustrojodawca bowiem $\mathrm{w}$ przypadku problematyki wyborczej nie powinien pozostawiać ustaw dawcy nadmiernej swobody w jej normowaniu. Trzeba ponadto zauważyć, że w regulacji konstytucyjnej ma miejsce wyraźne zróżnicowanie tej regulacji w zależności od tego, czy odnosi się ona do wyborów do organów stanowiących samorządu terytorialnego, czy do wyborów organów wykonawczych.

${ }^{10}$ Szerzej na temat większości z argumentów przemawiających za bądź przeciw ograniczeniu możliwości sprawowania urzędu wójta (burmistrza, prezydenta miasta) przez co najwyżej dwie kadencje zob. J. Bujny, K. Ziemski, Kilka uwag na temat zasadności ograniczenia kadencyjności wójtów (burmistrzów, prezydentów miast), „Samorząd Terytorialny” 2015, nr 12, s. 27-30 i przywołana tam literatura. 
W przypadku organów stanowiących samorządu terytorialnego Konstytucja w art. 169 ust. 2 ustanawia jedynie zasady prawa wyborczego, które mają być zastosowane podczas ich wyborów. Są nimi powszechność, równość, bezpośredniość i tajność. Trybunał Konstytucyjny zasadnie wywiódł więc w wyroku z 3 listopada 2006 r. w sprawie o sygn. akt K 31/06, że ustrojodawca pozostawił ustawodawcy pełną swobodę w określeniu zasad rozdziału mandatów, co jest nawet absolutnie zrozumiałe $\mathrm{z}$ uwagi na zróżnicowanie ( $\mathrm{w}$ tym szczególnie pod względem liczby mieszkańców) tak jednostek samorządu terytorialnego różnego szczebla, jak i wręcz tego samego szczebla ${ }^{11}$. W przypadku tych organów Konstytucja milczy nawet w tak istotnej kwestii, jak określenie cenzusów dla biernego prawa wyborczego, co również rozstrzygają dopiero stosowne postanowienia ordynacji wyborczej.

Zdaniem Bogusława Banaszaka te same przyczyny zadecydowały o pozostawieniu przez ustrojodawcę w art. 169 ust. 3 Konstytucji swobody dla ustawodawcy w zakresie regulacji sposobu wyborów i odwołania organów wykonawczych samorządu terytorialnego $^{12}$. W moim przekonaniu o lakoniczności tej regulacji zadecydował jednak również brak sprecyzowanej wizji samorządu terytorialnego w czasie uchwalania ustawy zasadniczej, kiedy nie było nawet pewne, czy zostaną przywrócone w Polsce powiaty i jaka będzie ich liczba, jak i ile będzie w Polsce województw.

Konstytucja nie przesądza nawet, czy organ wykonawczy samorządu terytorialnego ma być jednoosobowy, czy kolegialny. Dla czynionych tu uwag pewne znaczenie może mieć natomiast to, czy z treści art. 169 ust. 3 naszej ustawy zasadniczej, odsyłającego do ustawy jako aktu prawnego, w którym zostaną określone zasady i tryb wyboru oraz odwoływania organów wykonawczych jednostek samorządu terytorialnego, wynika konieczność przeprowadzania ich powszechnych i bezpośrednich wyborów. Za takim odczytaniem tego przepisu opowiada się Marcin Bąkiewicz ${ }^{13}$, co wynika jednak, moim zdaniem, z nadinterpretacji treści art. 62 ust. 1 i 2 Konstytucji o czynnym prawie wyborczym przedstawicieli do organów samorządu terytorialnego; cechy powszechności czynnego prawa wyborczego i biernego prawa wyborczego nie są przecież, jak słusznie zaakcentował Trybunał Konstytucyjny w wyroku z 24 listopada 2008 r. w sprawie o sygn. akt K 66/07, symetryczne ${ }^{14}$. Zasadnie przeważa jednak pogląd, iż art. 169 ust. 3 nie przesądza o tym, czy wybory tych organów mają mieć charakter powszechny, czy też mogą być dokonywane przez organy stanowiące ${ }^{15}$. Paweł Sarnecki napisał: „Konstytucja nie przesądza również sposobu desygnacji osób (osoby) — piastunów stanowisk w organie wykonawczym. Widać to wyraźnie z zestawienia ust. 2 i ust. 3 komentowanego artykułu. Sposobem tym może być zarówno wybór w głosowaniu powszechnym, jak i wybór przez organ stanowiący, czy też inny organ"16.

11 OTK-A 2006, Nr 10, poz. 147.

12 Zob. B. Banaszak, Uwaga 10 do art. 169, [w:] idem, Konstytucja Rzeczypospolitej Polskiej. Komentarz, Warszawa 2009.

${ }_{13}$ Zob. M. Bąkiewicz, System wyborczy do samorządu terytorialnego w Polsce na tle europejskim, Toruń 2008, s. 176.

${ }^{14}$ OTK ZU nr 9/A/2008, poz. 158, pkt 6.2.

15 Zob. np. B. Banaszak, op. cit.

${ }^{16}$ Zob. P. Sarnecki, Uwaga 4 do art. 169, [w:] Konstytucja Rzeczypospolitej Polskiej. Komentarz, t. IV, red. L. Garlicki, Warszawa 2005. 
Dla czynionych rozważań przywołanie wyroku w sprawie o sygn. akt K 66/07 ma szczególne znaczenie. Trybunał Konstytucyjny w jego uzasadnieniu bowiem odniósł się bezpośrednio do kwestii biernego prawa wyborczego podczas wyborów organów wykonawczych jednostek samorządu terytorialnego. Wywód ten przywołuję dlatego w całości. Zgodnie z nim

przepis art. 169 ust. 2 i 3 bezpośrednio odsyła do uregulowania w ustawie „zasad i trybu zgłaszania kandydatów”, „przeprowadzania wyborów”, określenia warunków ważności wyborów, a także „zasad i trybu wyborów oraz odwoływania organów wykonawczych jednostek samorządu terytorialnego". Co za tym idzie, Konstytucja pozostawia w tym wypadku ustawodawcy większy luz decyzyjny w zakresie regulacji praw wyborczych (w tym warunków posiadania biernego prawa wyborczego) niż w wypadku wyborów do Sejmu czy Senatu. Wynika to między innymi z konieczności uwzględnienia choćby specyfiki wyborów lokalnych (zob. wyrok TK z 3 listopada 2006 r., sygn. K 31/06, OTK ZU nr 10/A/2006, poz. 147). Trybunał podkreślił także, iż w wypadku organów wykonawczych jednostek samorządu terytorialnego Konstytucja pozostawia ustawodawcy określenie zasad i trybu ich wyboru. Nie przewiduje przy tym konieczności powoływania tych organów w trybie wyborów powszechnych. Co za tym idzie, wspomniany wcześniej luz decyzyjny, w zakresie kształtowania sposobu powoływania tych organów, pozostaje większy, niż w wypadku organów stanowiących jednostek samorządu terytorialnego ${ }^{17}$.

Konstytucja, co również należy podkreślić, nie przesądza nawet, czy organy samorządu terytorialnego mają być organami kadencyjnymi. Trybunał Konstytucyjny w wyroku z 31 marca 1998 r. w sprawie o sygn. akt K 24/97, zasadnie nawiązując do swojego wcześniejszego orzeczenia z dnia 23 kwietnia 1996 r. w sprawie K 29/95, wskazał, że konsekwencją ustanowienia wybieralności organów stanowiących samorządu terytorialnego jest ich kadencyjność, co oznacza między innymi wyznaczenie ram czasowych ich pełnomocnictwa ${ }^{18}$. Bez wątpienia można to odnieść również do organów wykonawczych samorządu terytorialnego $\mathrm{i}$ to nawet wówczas, gdy nie pochodzą one z wyborów powszechnych i bezpośrednich. W literaturze przedmiotu słusznie podnosi się przy tym, że z zasady kadencyjności organów samorządowych nie płyną żadne wyraźne nakazy bądź zakazy, a więc również zakaz kandydowania na ten sam urząd po pełnieniu go przez dwie kadencje ${ }^{19}$.

$\mathrm{W}$ literaturze przedmiotu w pełni zasadnie, moim zdaniem, polemizuje się wreszcie $\mathrm{z}$ argumentem, że ograniczenia w możliwości dopuszczalnej liczby kadencji, przez które można sprawować urząd w organach samorządu terytorialnego, są rozwiązaniem znanym w wielu innych państwach. Podnosi się, że przecież można wskazać wiele państw, w których również takie ograniczenie nie występuje. Przede wszystkim słusznie akcentuje się jednak odmienności występujące w różnych państwach odnośnie do wielkości jednostek samorządu terytorialnego, liczby ich mieszkańców, pozycji ustrojowej, jak i podmiotu, który rozstrzyga o ustroju wewnętrznym gminy, którym nie musi być władza krajowa ${ }^{20}$.

17 OTK ZU nr 9/A/2008, poz. 158, pkt 6.2.

18 OTK 1998, Nr 2, poz. 13.

19 J. Bujny, K. Ziemski, op. cit., s. 25-33.

20 Ibidem, s. 26-27 oraz przywołana tam opinia Pawła Chmielnickiego: idem, Opinia prawna dotyczaca poselskiego projektu ustawy o zmianie ustawy o samorzadzie gminnym oraz o zmianie innych ustaw (druk sejmowy nr 3834), Warszawa 2011, s. 9-10. 


\section{Możliwość obowiązywania zakazu reelekcji wójta (burmistrza, prezydenta miasta) podczas najbliższych wyborów samorządowych}

Przedstawienie problemu wprowadzenia zakazu kandydowania na urząd wójta (burmistrza, prezydenta miasta) przez osoby, które piastują już w danej gminie tę funkcję przez co najmniej dwie kadencje, wymaga odniesienia się do jeszcze jednej kwestii, a mianowicie niemożności startowania przez nie $\mathrm{z}$ tego powodu $\mathrm{w}$ tej gminie już podczas najbliższych wyborów samorządowych. Zwłaszcza przez samorządowców formułowany jest zarzut, że narusza to fundamentalną zasadę lex retro non agit, a więc niedziałania prawa wstecz. Jest on oparty na nieporozumieniu i braku świadomości, co w istocie oznacza, jak w pełni pokazał, i to w odniesieniu właśnie do podnoszonego tu problemu, Jerzy Zajadło ${ }^{21}$. Przez retroaktywność rozumie się cechę normy prawnej, polegającą na tym, że ustanawia ona pewne obowiązki w związku ze zdarzeniami, które miały miejsce w przeszłości, co jednak wówczas nie było określone jako mogące rodzić jakiekolwiek konsekwencje w przyszłości. Niewątpliwie jest to jedna z najbardziej ogólnych i podstawowych zasad prawa i aksjologiczny postulat, lecz nie ma charakteru absolutnego, bezwzględnego, dlatego znajdujemy od niej odstępstwa nawet w prawie karnym, gdzie ma ona przecież szczególne znaczenie. Bezwzględnej ochronie nie podlegają nawet prawa słusznie nabyte, jeżeli tylko przemawiają za tym inne racje, wartości. Należy też pamiętać, że w orzecznictwie Trybunału Konstytucyjnego dokonuje się rozróżnienia zakazanej, co do zasady, retroaktywności od dozwolonej retrospektywności, określanej mianem retroaktywności pozornej, która w przeciwieństwie do retroaktywności odnosi się do stosunków prawnych zaistniałych przed wejściem w życie przepisu, które jednak nadal trwają. Retrospektywność nie jest konstytucyjnie zakazana, ponieważ oznaczałoby to „nadmierne ograniczenie swobody władzy ustawodawczej w kształtowaniu i zmianach treści prawa oraz dostosowywania go do zmian społecznych"22. Przypomnieć również można, że przecież w nie tak odległej przeszłości mieliśmy nawet do czynienia z wprowadzaniem pewnych rozwiązań w trakcie kadencji, a nie dopiero od następnej, jak na przykład miało to miejsce w wypadku ustanowienia obowiązku składania oświadczeń majątkowych ${ }^{23}$. Tym samym ustawodawca ma prawo uznać, że po dwóch zakończonych kadencjach osoba pełniąca urząd wójta (burmistrza, prezydenta miasta) nie powinna już kandydować podczas najbliższych wyborów.

${ }^{21}$ Zob. J. Zajadło, Mit zakazu retroaktywności prawa, www.konstytucyjny.pl (dostęp: 25 stycznia 2017) i przywołana tam literatura.

22 Zob. wyrok Trybunału Konstytucyjnego w sprawie o sygn. akt K 11/04.

${ }^{23}$ Zob. wyroki Trybunału Konstytucyjnego w sprawach o sygn. akt K 11/01 i K 7/05. 


\section{Termin dokonania zmian w prawie wyborczym i ustanowienia zakazu reelekcji wójta (burmistrza, prezydenta miasta)}

W wypadku wprowadzenia rozpatrywanego zakazu istotny jest jednak, w moim przekonaniu, inny problem, który nie był, jak dotąd, w pełni podniesiony, a mianowicie kiedy najpóźniej przed wyborami powinien on wejść w życie. Jest to zatem kwestia okresu odpowiedniej vacatio legis adekwatnej do dokonywanej zmiany. Należy przypomnieć, że już w Kodeksie dobrych praktyk wyborczych tzw. Komisji Weneckiej mowa jest o tym, że niestosowne jest dokonywanie generalnych zmian w prawie wyborczym na krótko przed wyborami ${ }^{24}$. Do kwestii tej dwukrotnie odnosił się również Trybunał Konstytucyjny. Szczególne znaczenie ma w tej sytuacji przywoływany już wyrok z 3 listopada $2006 \mathrm{r}$. w sprawie o sygn. akt. K 31/06, dotyczący samorządowej ordynacji wyborczej (blokowanie list kandydatów). Trybunał nawiązał w nim do swojego wcześniejszego orzecznictwa, w którym akcentował, że zasada przyzwoitej legislacji wywodzona $\mathrm{z}$ art. 2 Konstytucji nakazuje, aby vacatio legis była dostosowana do funkcji ustawy, jaką pełni ona w systemie prawa, z jej charakterem i rodzajem relacji społecznych, które reguluje. Co do problematyki wyborczej uznał wówczas, iż można mówić o jej istotnych elementach, w wypadku których zmiany dopuszczalne są jedynie przy zachowaniu co najmniej sześciomiesięcznego terminu od ich wejścia w życie do pierwszej czynności kalendarza wyborczego. Podkreślił jednocześnie, iż jest to nieusuwalny, co do zasady, normatywny składnik treści art. 2 Konstytucji. Jak zaznaczył bowiem w Uzasadnieniu (odnosząc się do kwestii progów wyborczych czy sposobu przeliczania głosów na mandaty), zmiany powinny być wprowadzane z takim wyprzedzeniem po to, „aby wszyscy potencjalni »aktorzy« procesu wyborczego zdołali przeanalizować zmiany dotychczasowego stanu prawnego, a przede wszystkim dostosować swoje zachowania do nowych »reguł gry «". W wyroku z dnia 29 października 2009 r. w sprawie o sygn. akt Kp 3/09²5 (dotyczącej ordynacji wyborczej do Parlamentu Europejskiego) Trybunał Konstytucyjny uznał nawet, że te sześć miesięcy to minimum minimorum. Podkreśli też, że

„Istotną zmianą” w prawie wyborczym jest taka, która w wyraźny sposób wpływa na przebieg głosowania i jego wyniki i która w związku z tym wymaga uprzedzenia adresatów normy prawnej o jej wprowadzeniu. [...] Ważna jest tu ocena głębokości ingerowania przez nową regulację w istniejący system wyborczy. Im dana zmiana sięga głębiej w przebieg głosownia, tym okres „adaptacji” do niej po stronie wyborców, jak i organów przeprowadzających wybory musi być odpowiednio dłuższy.

Nie ulega dla mnie wątpliwości, że z „istotnością zmiany” będziemy mieć do czynienia w wypadku wprowadzenia ograniczenia w możliwości kandydowania na urząd wójta (burmistrza, prezydenta miasta) po co najmniej jego dwukrotnym sprawowaniu w danej gminie. Można nawet zastanawiać się, czy okres sześciu miesięcy przed początkiem kalendarza wyborczego to nie jest czas zbyt krótki na wprowadzenie tak istotnej

${ }^{24} \mathrm{Z}$ tego punktu widzenia samo wprowadzenie w 2002 r. bezpośrednich wyborów wójtów (burmistrzów, prezydentów miast) na dwa miesiące przed wyborami musi budzić krytyczną ocenę z uwagi na krótki czas, jaki pozostał na wypromowanie liderów mogących ubiegać się o ten urząd.

25 OTK ZU 9A/2009, poz. 138. 
zmiany, trzeba bowiem mieć na uwadze to, że dokonanie wyboru dobrego kandydata na tak ważny urząd i jego wypromowanie, zwłaszcza w dużych gminach miejskich, to szczególnie duży wysiłek.

\section{Podsumowanie}

Przeprowadzona analiza pokazuje, że - w moim przekonaniu - nie będzie można uznać za naruszenie Konstytucji wprowadzenia ustawowego ograniczenia możliwości kandydowania na wójta (burmistrza, prezydenta miasta) przez osobę, która w danej gminie piastowała ten urząd przez co najmniej dwie kadencje. Wynika to $\mathrm{z}$ nadmiernej lakoniczności regulacji najwyższego prawa w Rzeczypospolitej Polskiej w kwestii wyborów samorządowych. Można więc nawet powiedzieć, że postulatem na przyszłość jest znacznie pełniejsze i precyzyjniejsze uregulowanie tej kwestii w Konstytucji.

Nie będzie też naruszeniem ustawy zasadniczej obowiązywanie tej zasady już podczas najbliższych wyborów samorządowych i uniemożliwienie tym samym kandydowania wójtom (burmistrzom, prezydentom miast), którzy ten urząd już sprawują przez co najmniej dwie kadencje. Warunkiem jest jednak to, że zostanie ona wprowadzona co najmniej na sześć miesięcy przed zarządzeniem przez premiera wyborów samorządowych.

Uznanie przeze mnie w świetle regulacji konstytucyjnej dopuszczalności tego rozwiązania nie oznacza jednak, że je w pełni aprobuję. W szczególności nie podzielam argumentacji wskazującej, że za ustanowieniem takiego zakazu przemawia zakaz przewidziany w art. 127 ust. 2 Konstytucji, zgodnie z którym można być ponownie wybranym na urząd Prezydenta RP tylko raz. Najprostszym kontrargumentem jest to, że nie można porównywać zakresu zadań głowy państwa i organu wykonawczego w gminie, i to nawet w sytuacji, gdy jest to miasto na prawach powiatu. Przede wszystkim uważam jednak, w pełni przychylając się do stanowisk przedstawianych w literaturze przedmiotu, że z istoty samorządności lokalnej wynika, że decyzje w tej kwestii, kto ma sprawować urząd wójta (burmistrza, prezydenta miasta), powinny należeć do mieszkańców wspólnoty samorządowej, ingerencja w nie ze strony polityków i władz centralnych zaś powinna ograniczać się do niezbędnego minimum ${ }^{26}$. Nie jest nim ograniczenie możliwości ubiegania się o ten urząd osobom, które sprawują go w danej gminie już przez co najmniej dwie kadencje.

\section{Bibliografia}

Banaszak B., Konstytucja Rzeczypospolitej Polskiej. Komentarz, C.H. Beck, Warszawa 2009.

Bąkiewicz M., System wyborczy do samorzadu terytorialnego w Polsce na tle europejskim, Wydawnictwo Adam Marszałek, Toruń 2008.

Bujny J., Ziemski K., Kilka uwag na temat zasadności ograniczenia kadencyjności wójtów (burmistrzów, prezydentów miast), „Samorząd Terytorialny” 2015, nr 12.

Druk sejmowy nr 154 - IV kadencja.

26 J. Bujny, K. Ziemski, op. cit., s. 25-33. 
Druk sejmowy nr 428 - VI kadencja.

Druk sejmowy nr 1015 - VII kadencja.

Druk sejmowy nr 3834 - VII kadencja.

Konstytucja Rzeczypospolitej Polskiej. Komentarz, t. IV, red. L. Garlicki, Wydawnictwo Sejmowe, Warszawa 2005.

Skotnicki K., Opinia prawna na temat zgodności z Konstytucja art. 2 i art. 4-6 poselskiego projektu ustawyo zmianie ustawy o samorządzie gminnym oraz o zmianie innych ustaw zgłoszonego $w$ dniu 21 września 2010 r. przez Grupęposłów na Sejm RP Klubu Parlamentarnego „Prawo i Sprawiedliwość” (28 października 2010 r.). - BAS-WAUiP-17792/10.

Skotnicki K., Opinia prawna na temat poselskiego projektu ustawy o zmianie ustawy z 5 stycznia 2011 r. Kodeks wyborczy poprzez ustanowienia ograniczenia wykonywania mandatu posta, senatora oraz sprawowania urzędu wójta (burmistrza, prezydenta miasta) jedynie przez dwie kadencje (15 listopada 2013 r.) - niepublikowane (zlecenie 2692/13).

Tarasek M., Wprowadzenie ograniczenia kadencyjności wójta, burmistrza, prezydenta miasta w pracach polskiego parlamentu, „Polityka Społeczna” 2016, nr 2.

Ustawa z dnia 20 czerwca 2002 r. o bezpośrednim wyborze wójta, burmistrza i prezydenta miasta (t.j. Dz.U. z 2010 r. Nr 176, poz. 1191).

Wyrok z 31 marca 1998 r. w sprawie K 24/97, OTK 1998, nr 2, poz. 13.

Wyrok z 8 października 2001 r. w sprawie K 11/01, OTK ZU nr 7/2001, poz. 210.

Wyrok z 3 listopada 2006 r. w sprawie o sygn. akt K 31/06, OTK ZU nr 10/A/2006, poz. 147.

Wyrok z 24 listopada 2008 r. w sprawie o sygn. akt K 66/07, OTK ZU nr 9/A/2008, poz. 158.

Wyrok z 28 października 2009 r. w sprawie Kp 3/09, OTK ZU 9/A/2009, poz. 138.

Zajadło J., Mit zakazu retroaktywności prawa, http://konstytucyjny.pl/mit-zakazu-retroaktywnosci-prawajerzy-zajadlo/ (dostęp: 25 stycznia 2017).

\section{On the admissibility of the ban on the re-election of the mayor (city president) after holding office for two terms}

Keywords: local self-government, election, community, mayor, term of office

\section{Summary}

The principle of direct election of mayors (presidents of cities) has been in force in Poland since 2002. At the same time, the idea of limiting the possibility of holding office for two terms has started. The analysis leads the author to the conclusion that in view of the laconic nature of the constitutional regulation of local elections, such solution cannot be considered as contrary to the Constitution. The decision about who will act as the executive body of the commune should, however, belong to the inhabitants of the local government. 